\title{
公開資料
}

研究開発成果実装支援プログラム

実装活動の名称「応急仮設住宅の生活環境改善のため の統合的実装活動プログラム」

緊急実装支援プロジェクト終了報告書

実装期間 平成 23 年 5 月 平成 24 年 3 月

実装機関名福島大学

実装責任者

氏 名 丹波 史紀 


\section{I 実装活動の名称と目標、1年間の活動要約}

\section{(1) 実装活動の名称}

\section{「応急仮設住宅の生活環境改善のための統合的実装活動プログラム」}

\section{(2) 最終目標}

ハード（集会所・診療所・ケア付き仮設・コミュニティバスなど）・ソフト（見守り支 援・子どもの学習環境・ボランティアセンターなど）両面から応急仮設住宅の生活環境の 改善を図り、被災者のQOL向上に寄与する。

阪神・淡路大震災、新潟県中越地震や新潟県中越沖地震など一連の仮設住宅における課 題と改善の成果をいかしつつ、東日本大震災における応急仮設住宅の設置・運営に伴うコ ミュニティ維持・再生を図り、被災者生活再建と今後の災害支援システムのブラッシュア ップに寄与する。自治体およびNPO・ボランティアとの連携システムを整備し、応急仮設住 宅の設置・運営をハード・ソフトの両面にわたって実装活動を行う。

具体的には、以下のような条件を整備する。

(1) 応急仮設住宅群ごとの集会所の設置

(2) 応急仮設住宅群ごとの診療所機能（もしくは往診体制）の設置

(3) 高齢者向けケア付き仮設住宅の設置

(4) 子どもの学習環境・居場所づくり

(5)孤独死を生まない巡回相談（見守り）活動の体制整備

６）社会福祉協議会や常駐型ボランティアの事務所機能の設置

(7) コミュニティバス整備などの交通手段の確保

\section{（3）支援期間終了後の目標（到達点）}

具体的には、以下のような時期区分を行い、実装活動を展開する。

<第一目標 $>$ 応急仮設住宅の建設予定時期の 7 月末まで

上記の (1)、(2)、(3)な゙については 7 月末の応急仮設住宅の建設を第一目標とハード面で の実装活動を展開する。特に福島県内の建設事業者が発注を受ける4000戸の応急仮設住宅 に対し、実装活動を行う。また福島大学と飯舘村は相互に協定を結んでいる活動から、計 画避難において被災者支援やコミュニティ維持などでの貢献を求められている。こうした ことも考慮し、実際の実装活動においては、柔軟に対応できるようにする。

＜第二目標＞ 応急仮設住宅の建設後も見通した年内まで

さらに、上記(4)、(5)、(6)、7)については 7 月末以降建設が終了した後、具体的な実装活動 
を年内に実装活動を行う。特に、二次避難所であるホテル・旅館から応急仮設住宅までを 見通した継続的な見守り支援体制の整備を 5 月下旬より行う。

$<$ 第三目標 $>$

上記の実装活動が、適切に実装されたかどうかをモニタリングし、今後の課題や改善に つなげる。

\section{(4)1年間の活動実績（要約）}

「応急仮設住宅の生活環境改善のための統合的実装活動プログラム」では、仮設住宅に おける被災者の生活環境改善のための実装活動を展開した。

ハード面では、福島県土木部などと協議・連携を図り、県内16000戸の仮設住宅建設のう ち、6000戸を福島県内の建設業者にプロポーザル形式でコンペし選定した。なお研究代表 者の丹波は、この公募選定委員として専門的知見からの助言や意見した。結果6000戸のう ち5500戸が木造型の仮設住宅となり、「福島方式」と呼ばれるゆえんとなった。さらに、 県内約20か所の仮設住宅団地において、「高齢者サポート拠点」によるサポートセンター の設置も行われた。

こうした取り組みに対し、この度の実装活動チームが少なからず関わったが、それをさ らに発展させるために福島県と福島大学（実装活動チーム）が中心となり、2011年10月に 東京大学・筑波大学 $\cdot$ 日本大学工学部 - 長岡技術科学大学 - 国交省国土技術政策総合研究 所・独立行政法人森林総合研究所・福島県建築士会など関係機関の参画も得て、「福島県 応急仮設住宅等の生活環境改善のための研究会」を設置し、これまで準備会を含めると4 回の研究会を行っている。

ソフト面では、サポートセンターの設置にともない、自治体と社会福祉協議会、委託事 業者と実装活動チームの 4 者で運営についての定期的な連絡会を設けるなどし、効果的な 支援につなげられるようにしている。さらに丹波が代表理事をつとめる「ふくしま連携復 興センター」とも連携し、県内の仮設住宅全てを対象にしたアセスメント調査活動も行い、 先頃発表した。こうした調査結果を基にしながら、仮設住宅における効果的な被災者支援 につなげる取り組みを進めている。たとえば、子どもの学習支援活動をNP0 と行政が連携し 取り組んでいることや、企業との積極的な連携により被災者のコミュニティ形成への寄与 についても取り組んでいるところである。 


\section{II＼cjkstart実装活動の計画と実装活動}

\section{(1) 全体計画}

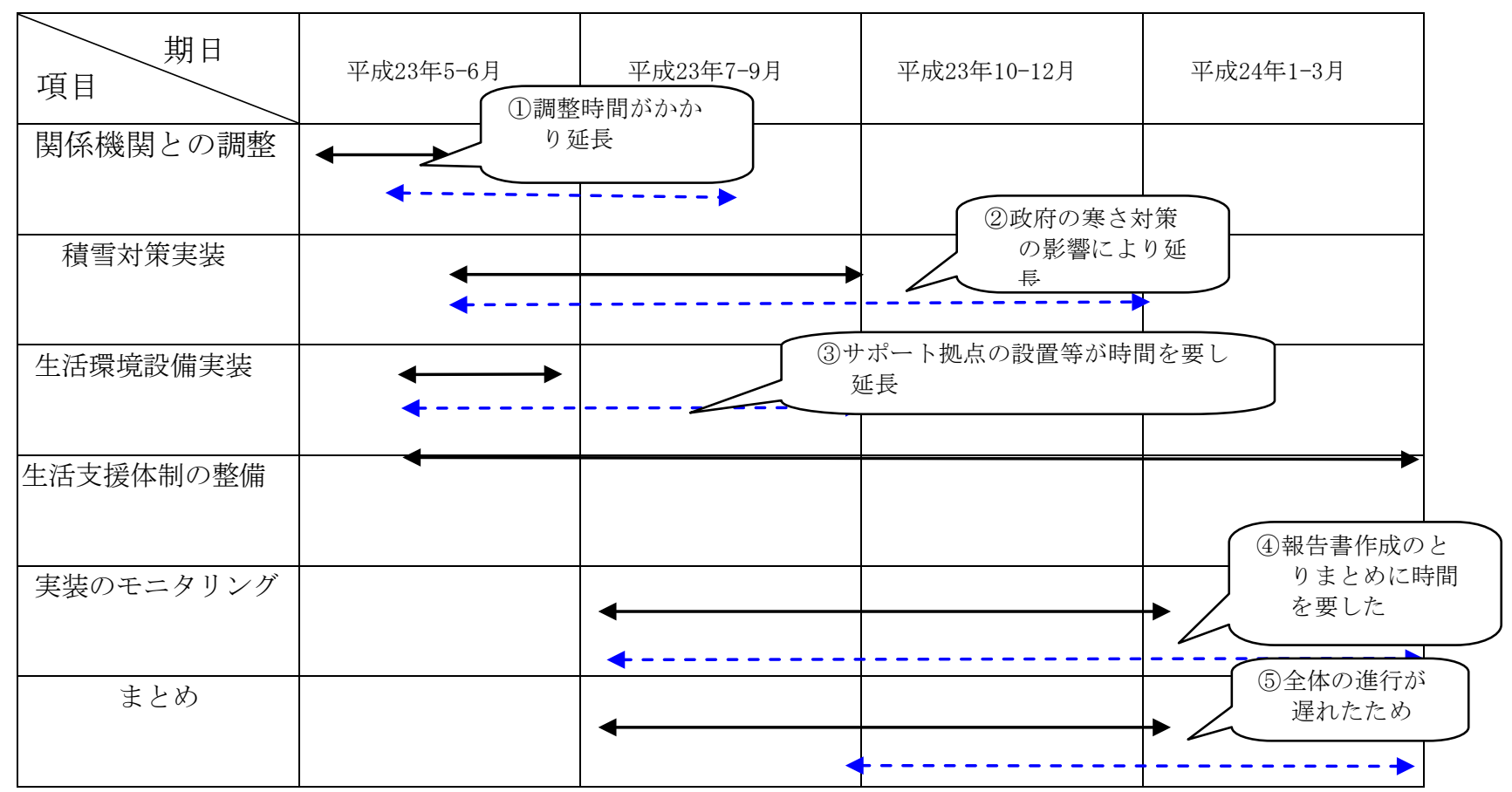

\section{(2) 実装活動の具体的内容}

福島県などの自治体と連携し、避難生活であっても「生活の質」を重視し、人々の生活 環境改善のための取り組みを進めた。

ハード面では、仮設住宅の建設においては、16000戸のうち6000戸を県内建設業者に発注 することにより、地元の企業の仕事づくりや雇用創出などにも貢献した。さらに、6000戸 のうち5500戸が木造型の仮設住宅になり、従来のプレハブ型仮設住宅ではない形での居住 空間を被災者に一定提供することができた。騒音や断熱対策などについては、当初の想定 を修正して追加的工事をしなければならない部分があった。当初から福島県などにはペア 硝子・断熱材の強化などを助言してきたが、結果として我々の提言が追加的に実施される ことになった。こうした取り組みを経て、福島県と実装チームおよび関係する大学・研究 機関で、2011年10月より「福島県応急仮設住宅等の生活環境改善のための研究会」（構成 メンバー：福島県土木部・福島大学・東京大学・筑波大学・日本大学工学部・長岡技術科 学大学・国交省国土技術政策総合研究所・（独法）森林総合研究所・福島県建築士会）を つくり、定期的な研究会を通じ、「福島型木造仮設住宅」の汎用化および仮設住宅の今後 のあり方などについて調査研究を重ねている。福島大学はそのとりまとめを行っている。 実装支援プログラムの展開を通じ、本実装支援チームが中心となり連携協定を福島大学と 結ぶこととなった帝人グループと、プレハブ型仮設住宅および木造仮設住宅における騒音 
と断熱の効果検証のための共同プロジェクトを展開中である。

またソフト面では、県内仮設住宅のうち、約20か所の大型仮設住宅団地においては「高 齢者サポート拠点」を整備することができ、高齢者を含む被災者全体の総合支援の取り組 みの一歩ともなった。研究代表者の丹波は、この高齢者サポート拠点の公募委員もつとめ、 必要に応じて拠点整備に対し意見した。さらに実装支援チームでは、飯舘村とサポート拠 点委託事業者、村の社会福祉協議会、福島大学の4者で定期的に会合を持つなどし、サポー 卜拠点の内容について意見調整をしながらすすめるなどした。

また、県内のNP0団体のネットワーク組織である「ふくしま連携復興センター」と連携し、 県内の被災者支援に取り組んだ。たとえば、仮設住宅団地における面的な環境アセスメン 卜を県内全ての仮設住宅において行ったこと、さらに仮設住宅内における子じもの学習支 援活動を県内各方部でNP0と大学が連携し取り組んでいる。さらに福島市内NP0団体と連携 し、これまであったコミュニティバスを仮設住宅まで巡回することにより、新たな費用を かけることなく、被災者の移動支援につながる取り組みも行われた。また企業との連携も す寸め、KDDIとはみなし仮設住宅を含む住民のコミュニケーションツールとして、各世帯 にタブレットの配布検討などの取り組みにつながっている。

こうした取り組みはさらに進める予定であり、実装支援プログラムの展開が新たな研究 機関や企業との連携にも至っている。実装支援プログラムの展開がきっかけとなり、さら に自治体・企業・NPOなど多様なステークホルダーの参画により被災地の復興に引き続き取 り組む土壌ができあがった。今後継続的な展開が期待されるところである。

ただし、今回の実装支援プログラムでは、当初予想していなかった事態も生まれ、課題 もあった。今回の災害では応急仮設住宅以上に民間賃貸住宅を自治体が借り上げる、いわ ゆる「みなし仮設住宅」が急増し、23000戸以上になった。こうしたみなし仮設住宅は、地 域に点在し、被災者が孤立する傾向にあり、こうしたみなし仮設住宅を含む被災者全体の 支援のネットワーク化が今後の課題となっている。この点、被災自治体や県内NPOなどと連 携し、バラバラになった住民の絆を断ち切らず、コミュニティをどう維持していくか、そ のための枠組みをどう作り出すかは今後の課題である。 


\section{III 実装支援活動の成果}

\section{(1) 目標達成及び実装状況}

\begin{tabular}{|c|}
\hline 【支援期間終了後の目標 (到達点)】 \\
ハード・ソフ面での仮設住宅団地にお \\
ける被菼者のQOL 向上 \\
実装対象: 福島県全域 \\
\\
\end{tabular}

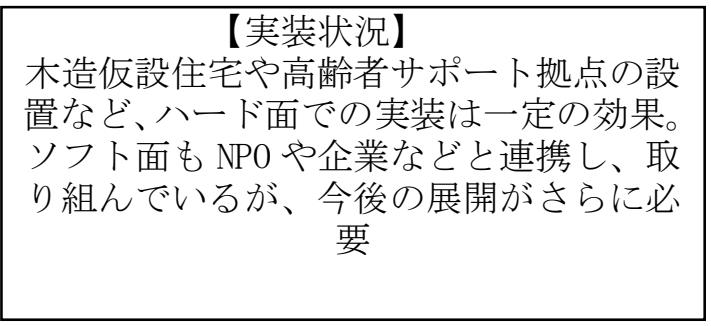

\section{(2)実装された成果の今後の自立的継続性}

ハード面ではおおむね一定の成果を得ることができた。しかし、現在仮設住宅の再編や 集約化が議論されており、それが実現する場合に、さらに今回の実装活動で得られた知見 を展開する必要がある。たとえば、木造仮設住宅の復興公営住宅など本設への転用など、 さらなる実装活動の展開が期待される。

またソフト面では、当初の予想以上の進展に対する対応が必要となった。福島県では、1 6000戸の仮設住宅に対し、23000戸の「みなし仮設住宅」に被災者の多くが入ることになっ た。「被災者支援」という点では、仮設住宅のみならず、みなし仮設住宅の被災者をも視 野に入れた支援の枠組みを作る必要がある。この点では、富岡町と「おだがいさまセンタ 一」（被災者サポートセンター）が個人情報の取扱に関する覚書を取り交わし、広域的な 支援を行うなどの展開も生まれている。こうした事例に学びながら、さらに被災者支援の ネットワーク化に取り組んでいく必要がある。

なお、前述のように、福島県と連携研究機関等による研究会の設置、さらには企業やNP 0などとの連携なども進んでおり、今後の展開の足がかりとなり得る。

\section{（3）実装活動の他地域への普及可能性}

今回の実装支援活動において、「福島方式」と呼ばれる木造仮設住宅を県内事業者が建 設するという方式は、今後の災害にも大いに普及する可能性を有している。プレハブ建設 協会による仮設住宅の供給でなくとも、県内事業者が積極的な役割を果たすことによって、 仕事づくり・雇用確保など経済波及効果も大きい。

さらに、今回被災者支援で課題となっている「みなし仮設住宅」は、将来の災害時、と りわけ首都直下型地震のような都市型災害の際には、当然起こりうる同様の課題であり、 今回の災害を通じ、コミュニティがバラバラになった被災者をじうつなぎ直すのか、その ための支援を行政・被災者・NPO等が協働で構築できるかが喫緊の課題となっている。 


\section{（4）実装活動の社会的副次成果}

実装活動の副次的効果として、自治体と協力し、原発周辺自治体の双葉郡 8 町村の全住 民を対象にした「双葉 8 町村住民実態調査」を行うことができた。双葉郡に生活をしてい た約 3 万世帯を対象にしたこの調査は、福島大学災害復興研究所（主任 : 丹波史紀）が震 災から半年の 9 月に行ったもので、約13500世帯からの回答を得ることができ、原発避難者 の実態を大規模調査によって明らかにしたことが大きな社会的反響をよび、新聞・テレビ などのメディアでも繰り返し引用された。また国会質疑などにも本調査結果が利用された り、賠償問題を議論する原子力賠償紛争審査会において、丹波が本調査結果を報告するな どに結びついている。

さらに、仮設住宅等における被災者の生活環境の改善にとどまらず、広く福島の復興を検討す るために、福島大学大学院の東京サテライトを開設し、「ふくしま復興学」と名付けた人材育成 にもつなげている。実装活動チームの多くは、その教育スタッフとして携わっている。なお、こ の東京サテライトの仮設記念フォーラムを 2 月 6 日に東京都内で行い、ノーベル経済学賞受賞者 のアマルティア・セン氏にお願いし、当日は400名以上の参加者を得た。

また、学内でも実装活動チームも参画する形で、学内の震災復興にかかわるセンターとして、 「うつくしまふくしま未来支援センター」を創設。地域復興や産業復興、放射線対策や子どもサ ポートなどを総合的に取り組むセンターの設立にもつながっていった。

\section{(5) 人材育成}

実装活動を通じて、院生などの積極的な参加も促した。たとえば、「福島県応急仮設住 宅等の生活環境改善のための研究会」では、日本大学工学部や東京大学の大学院生なども 研究会に参加し、積極的に実装活動に携わることができた。

\section{（6）実装活動で遭遇した問題とその解決策}

今回の実装支援プログラムでは、当初予想していなかった事態も生まれ、課題もあった。 今回の災害では応急仮設住宅以上に民間賃貸住宅を自治体が借り上げる、いわゆる「みな し仮設住宅」が急増し、23000戸以上になった。ここに被災者全体のおよそ半数が生活し、 とくに若い層ほど入居する傾向にある。そのため、地域間のみならず世代間を含むコミュ ニティの維持・再生が大きな課題である。こうしたみなし仮設住宅は、地域に点在し、被 災者が孤立する傾向にあり、こうしたみなし仮設住宅を含む被災者全体の支援のネットワ ーク化が今後の課題となっている。この点、被災自治体や県内NPOなどと連携し、バラバラ になった住民の絆を断ち切らず、コミュニティをじう維持していくか、そのための枠組み をどう作り出すための取り組みを県・被災自治体およびNPOなどと連携し取り組んでいる。 


\section{IV 実装活動の組織体制}

\section{体制}

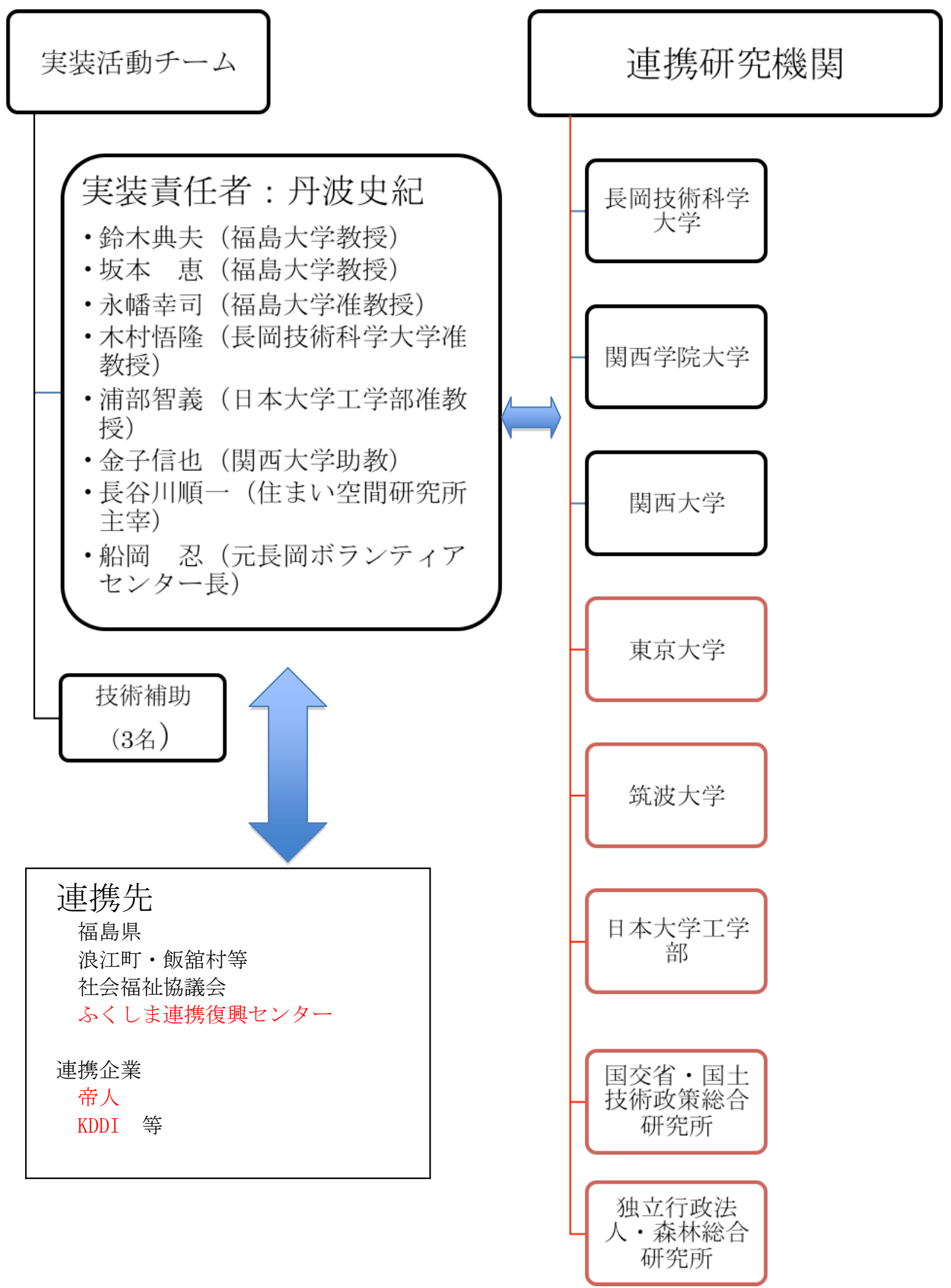




\section{$\mathrm{V} \quad$ 理解普及のための活動とその評価}

(1) 展示会への出展等

\begin{tabular}{|l|l|l|l|l|l|}
\hline 年月日 & 名称 & 場所 & 概要 & $\begin{array}{l}\text { ステーク } \\
\text { ホルダー }\end{array}$ & $\begin{array}{c}\text { 社会的 } \\
\text { クンパ } \\
\text { クト }\end{array}$ \\
\hline & & & & & \\
\hline & & & & & \\
\hline
\end{tabular}

(2) 研修会、講習会、観察会、懇談会、シンポジウム等

\begin{tabular}{|c|c|c|c|c|c|}
\hline 年月日 & 名称 & 場所 & 概要 & $\begin{array}{l}\text { ステーク } \\
\text { ホルダー }\end{array}$ & $\begin{array}{l}\text { 社会的 } \\
\text { インパ } \\
\text { クト }\end{array}$ \\
\hline $\begin{array}{l}2011 \text { 年 } \\
6 \text { 月 } 11 \text { 日 }\end{array}$ & $\begin{array}{l}\text { 東日本大震災災害復興 } \\
\text { シンポジウム }\end{array}$ & 福島大学 & 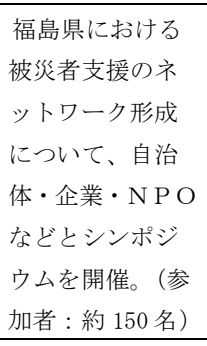 & $\begin{array}{l}\text { 福島県・双 } \\
\text { 葉 } 8 \text { 町村· } \\
\text { N P O等 }\end{array}$ & $\begin{array}{l}\text { 被災者支援 } \\
\text { のネットワ } \\
\text { ークガくり } \\
\text { の意見交換 } \\
\text { の場が定期 } \\
\text { 的に持たれ } \\
\text { るようにな } \\
\text { った。 } \\
\end{array}$ \\
\hline $\begin{array}{l}2011 \text { 年 } \\
6 \text { 月 } 12 \text { 日 }\end{array}$ & $\begin{array}{l}\text { 東日本大震災シンポジウ } \\
\text { 厶 }\end{array}$ & 早稲田大学 & $\begin{array}{l}\text { 県外避難者の支 } \\
\text { 援につてて東京 } \\
\text { に避難した者の } \\
\text { 態とその支援 } \\
\text { について議論す } \\
\text { る。(参加者: 約 } \\
100 \text { 名) }\end{array}$ & $\begin{array}{l}\text { 福島県・東 } \\
\text { 京都・社会 } \\
\text { 福祉協議会 } \\
\text { 等 }\end{array}$ & $\begin{array}{l}\text { 県外避難者 } \\
\text { の調查研究 } \\
\text { につながっ } \\
\text { ていく。 }\end{array}$ \\
\hline $\begin{array}{l}\text { 2011年 } \\
\text { 8月27日 }\end{array}$ & $\begin{array}{l}\text { 総合社会福祉研究所総 } \\
\text { 会講演「東日本大震災· } \\
\text { 福島原発と日本の社会 } \\
\text { 福祉」 }\end{array}$ & $\begin{array}{l}\text { 立命館大学 } \\
\text { 二条キャンパス }\end{array}$ & $\begin{array}{l}\text { 福島県の被災状 } \\
\text { 況と木造仮設住 } \\
\text { 宅や県外避難者 } \\
\text { の実態につつて } \\
\text { 報告。(参加者： } \\
\text { 約 } 400 \text { 名) }\end{array}$ & $\begin{array}{l}\text { 福島県・医 } \\
\text { 療・福祉専門 } \\
\text { 職 }\end{array}$ & $\begin{array}{l}\text { 災害時要援 } \\
\text { 護者問題 } \\
\text { など、被岁 } \\
\text { 者の実態 } \\
\text { を明らか } \\
\text { にするこ } \\
\text { とにつな } \\
\text { がった。 }\end{array}$ \\
\hline $\begin{array}{r}2011 \text { 年 } \\
9 \text { 月 } 16 \text { 日 }\end{array}$ & $\begin{array}{l}\text { 行政書士会·講演「地域 } \\
\text { 福祉・社会福祉のあり方 } \\
\text { 一震災復興における行 } \\
\text { 政書士の役割」 }\end{array}$ & $\begin{array}{l}\text { コラッセふくしま4 } \\
\text { 02会議室 }\end{array}$ & $\begin{array}{l}\text { 行政書士に、東日 } \\
\text { 本大震災・福島原 } \\
\text { 発事故の実態に } \\
\text { ついて報告し、司 } \\
\text { 法分野の専門職 } \\
\text { が果たす役㲅に } \\
\text { ついて議論する。 } \\
\text { (参加者: 約 } 50 \\
\text { 名) }\end{array}$ & 行政書士会等 & $\begin{array}{l}\text { その後、弁 } \\
\text { 護士や司 } \\
\text { 法書士な } \\
\text { どともに、 } \\
\text { 司法分野 } \\
\text { の専門職 } \\
\text { ネットワ } \\
\text { ークづく } \\
\text { りの議論 } \\
\text { につなが } \\
\text { る。 }\end{array}$ \\
\hline $\begin{array}{l}2011 \text { 年 } \\
10 \text { 月 } 2 \text { 日 }\end{array}$ & $\begin{array}{l}\text { FURE シンポジウム「ふた } \\
\text { ばはひとつ」 }\end{array}$ & 福島大学 & 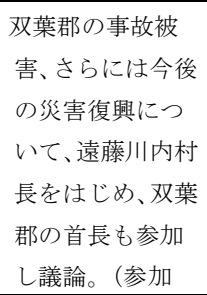 & $\begin{array}{l}\text { 福島県・双葉 } \\
8 \text { 町村・「うっ } \\
\text { くしま未来 } \\
\text { 支援センタ } \\
\text { 一」(FURE) }\end{array}$ & $\begin{array}{l}\text { 双葉郡と福 } \\
\text { 島大学が } \\
\text { 災害復興 } \\
\text { に関わる } \\
\text { 包括協定 } \\
\text { を結ぶき } \\
\text { っかけと }\end{array}$ \\
\hline
\end{tabular}




\begin{tabular}{|c|c|c|c|c|c|}
\hline & & & 者：約 250 名） & & なる。 \\
\hline $\begin{array}{c}2011 \text { 年 } \\
10 \text { 月 } 28 \text { 日 }\end{array}$ & $\begin{array}{l}\text { 福島県社会保険労務士 } \\
\text { 講演 }\end{array}$ & $\begin{array}{l}\text { 郡山・男女共生 } \\
\text { センター }\end{array}$ & $\begin{array}{l}\text { 司法書士に、東日 } \\
\text { 本大震災・福島原 } \\
\text { 発事故の実態に } \\
\text { ついて報告し、司 } \\
\text { 法分野の専門職 } \\
\text { が果たす役割に } \\
\text { ついて議論する。 } \\
\text { (参加者 : 約 } 50 \\
\text { 名) }\end{array}$ & 司法書土会 & $\begin{array}{l}\text { その後、弁 } \\
\text { 護土や司 } \\
\text { 法書士な } \\
\text { ぞともに、 } \\
\text { 司法分野 } \\
\text { の専門職 } \\
\text { ネットワ } \\
\text { ークづく } \\
\text { りの議論 } \\
\text { につなが } \\
\text { る。 }\end{array}$ \\
\hline $\begin{array}{c}2011 \text { 年 } \\
11 \text { 月 } 18 \\
\text { 日・2月 } 1 \\
\text { 日 }\end{array}$ & $\begin{array}{l}\text { JICA二本松_協力隊訓練 } \\
\text { 生向け講演 }\end{array}$ & JICA 二本松 & $\begin{array}{l}\text { JICA の協力隊研 } \\
\text { 修生に向け、東 } \\
\text { 日本大震㶤・福島 } \\
\text { 原発事故の実態、 } \\
\text { さらに実装活動 } \\
\text { チームで取り組 } \\
\text { んでいることを } \\
\text { 報告。(参加者： } \\
\text { 各約 } 200 \text { 名) }\end{array}$ & 福島県・JICA & $\begin{array}{l}\text { 協力隊研修 } \\
\text { 生が、海外 } \\
\text { 任地に拉 } \\
\text { いて日本 } \\
\text { の現状を } \\
\text { 伝えるた } \\
\text { めの基䃈 } \\
\text { 的な理解 } \\
\text { につなが } \\
\text { る。 }\end{array}$ \\
\hline $\begin{array}{c}2011 \text { 年 } \\
11 \text { 月 } 20 \text { 日 }\end{array}$ & 日本福祉大学 講演会 & 美浜キャンパス & $\begin{array}{l}\text { 日本福祉大学に } \\
\text { 招聘され、福島の } \\
\text { 被災実態と実装 } \\
\text { 活動チームの取 } \\
\text { り組みについて } \\
\text { 方向。(参加者： } \\
\text { 約 } 70 \text { 名) }\end{array}$ & $\begin{array}{l}\text { 日本福祉大学 } \\
\text { の教職員・学 } \\
\text { 生 }\end{array}$ & 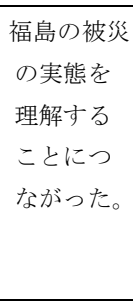 \\
\hline $\begin{array}{c}2011 \text { 年 } \\
11 \text { 月 } 24 \text { 日 }\end{array}$ & $\begin{array}{l}\text { 大阪経済法科大学・市民 } \\
\text { シンポジウム }\end{array}$ & $\begin{array}{l}\text { 近鉄八尾駅・プリ } \\
\text { ズムホール }\end{array}$ & $\begin{array}{l}\text { 大阪経済法科大 } \\
\text { 学に招聩され、シ } \\
\text { ンポジウムで福 } \\
\text { 島の被災の態 } \\
\text { を報告。(参加 } \\
\text { 者 : 約 } 300 \text { 名) }\end{array}$ & $\begin{array}{l}\text { 大阪経済法科 } \\
\text { 大学の教職 } \\
\text { 員・学生 }\end{array}$ & $\begin{array}{l}\text { 福島の被多 } \\
\text { の実態を } \\
\text { 理解する } \\
\text { ことにつ } \\
\text { ながった。 }\end{array}$ \\
\hline $\begin{array}{c}2011 \text { 年 } \\
11 \text { 月 } 26 \text { 日 }\end{array}$ & $\begin{array}{l}\text { 神戸大学都市安全研究 } \\
\text { センターオープンゼミナ } \\
\text { ール講演 }\end{array}$ & $\begin{array}{l}\text { 神戸大学工学研 } \\
\text { 究科C1-301教室 }\end{array}$ & $\begin{array}{l}\text { 神戸大学都市安 } \\
\text { 全研究センター } \\
\text { に招聘され、福島 } \\
\text { 県の仮設住宅の } \\
\text { 実態について報 } \\
\text { 告。(参加者: 約 } \\
50 \text { 名) }\end{array}$ & $\begin{array}{l}\text { 神戸大学执 } \\
\text { び一般市民 }\end{array}$ & $\begin{array}{l}\text { その後、継 } \\
\text { 続的に神 } \\
\text { 戸大学と } \\
\text { は被災地 } \\
\text { の復興に } \\
\text { 関わって } \\
\text { 議論が続 } \\
\text { けられる } \\
\text { ようにな } \\
\text { った。 }\end{array}$ \\
\hline $\begin{array}{c}2011 \text { 年 } \\
12 \text { 月 } 2 \text { 日・ } \\
7 \text { 日 }\end{array}$ & $\begin{array}{l}\text { 地域包括支援センター職 } \\
\text { 員研修 }\end{array}$ & $\begin{array}{l}\text { 県農業総合セン } \\
\text { ター }\end{array}$ & $\begin{array}{l}\text { 地域包括支援セ } \\
\text { ンターの職員向 } \\
\text { けに、災害復興と } \\
\text { 地域包括ケアの } \\
\text { 重要性について } \\
\text { 講演。(参加者： } \\
\text { 各約 } 60 \text { 名) }\end{array}$ & $\begin{array}{l}\text { 福島県・県社 } \\
\text { 会福禅蚠議 } \\
\text { 会・地域把括 } \\
\text { 支援セン夕 } \\
\text { 一職員 }\end{array}$ & $\begin{array}{l}\text { 地域包括々 } \\
\text { アを担う } \\
\text { 職員に、被 } \\
\text { 災者支援 } \\
\text { のネット } \\
\text { ワークつ } \\
\text { くりの重 } \\
\text { 要性と包 } \\
\text { 括の果た } \\
\text { す役割に } \\
\text { ついて理 } \\
\text { 解が深ま }\end{array}$ \\
\hline
\end{tabular}




\begin{tabular}{|c|c|c|c|c|}
\hline & & & & る。 \\
\hline $\begin{array}{l}2012 \text { 年 } \\
1 \text { 月 } 8 \text { 日 }\end{array}$ & $\begin{array}{l}\text { 全国被災地交流集会講 } \\
\text { 演 }\end{array}$ & 関西学院大学 & $\begin{array}{l}\text { 関西学院大学災 } \\
\text { 害復興制度研究 } \\
\text { 所が行う、「全国 } \\
\text { 被災地交流集会」 } \\
\text { にて、福島の被災 } \\
\text { 実態と今後の復 } \\
\text { 興につてて報告。 } \\
\text { (参加者: 約 } 150 \\
\text { 名) }\end{array}$ & \\
\hline
\end{tabular}

\section{（3）新聞報道、TV放映、ラジオ報道、雑誌掲載等}

(1) 新聞報道

2011. 11. 8, 毎日新聞, 原発避難住民「戻る気ない」 $27 \% \quad 8$ 町村全世帯アンケート 34 歳以下は 5 割強

2011.11.9 毎日新聞, 双葉郡調査「居場所なく浮草」避難住民将来見えぬ不安

2011.10.22 新潟日報,一被災地の仮設住宅一「中越」の教訓生かしに差

2011. 10.3 朝日新聞, 復興「地方全体で」

2011. 12.6 中国新聞, 丹波史紀・福島大准教授に聞く「居住地に戻る気ない」 $26.9 \%$ 国への不信 感が背景

2012.1.31 福島民友,「住民と行政＼cjkstart協力を」福島で丹波准教授講演

2012.1.27 福島民友, 町内外に集団移住先を 浪江町復興ビジョン検討委

2012.3.2 朝日新聞, 大学から復興活動を発信 福島大フォーラム

2012.3.3 朝日新聞, カストロ前議長「来年福島へ」震災支援者らとハバナで語り合う

2012.4. 3 福島民友, 県内仮設 1 割で公共交通未整備 連携復興センターなど調查

2012.3.26 東北復興新聞, 福島大学、世界へ情報発信 カストロ前議長やニューヨーク専門家へ 2012.2.23 朝日新聞, 個々の決断尊重し、支援する枠組みを

2012.3.11 朝日新聞, 住宅や仕事 改善の兆しなし

(2) TV 放映

2011.11.9 NHK, NHK おはよう日本

2012.3.10 TUF, 大震災・原発事故から一年〜これからの福島は II 〜

(3) ラジオ報道

2011.8.5 NHK ラジオ, ニュースここ一番

2011.12.8 NHK ラジオ,ニュースここ一番

2012.3.8 NHK ラジオ,ニュースここ一番

(4) 雑誌掲載

1）「東京消防」20012.1, 1 月号, 東日本大震災「絆」,2012. 1.10 発行, 91 巻 1 号，（財）東京消防 協会

2) IEICE , 2011. 12. 1, Communication Society－GLOBAL NEWSLETTER～(VOL. 35 No. 4 Dec. 2011) Contributing to the Reconstruction of Affected Areas through the Establishment of the Fukushima Disaster Recovery Institute. 電子情報通信学会

3) Guideline（2011.11）, 他大学、企業、自治体などと連携して現実の課題に適用できる研究を推 進, 河合塾/全国進学情報センター

4) JANU（2011. 10）, 福島県自治体の復興に貢献する, 福島大学災害復興研究所, 一般社団法人国立 大学協会

5）「建築とまちづくり」（November/December. 2011）, 強いられる長期の避難生活 生活再建の展 望, 2011. 11. 1 発行, 403 号, 新建築家技術者集団

6)「広島ジャーナル」(2012 年 3 月 第 8 号), 大事なのは人間の復興 何よりも暮らしの再建 各 人の選択尊重が起点, 2012.3.15 発行, 日本ジャーナリスト会議広島支部

7) JIR 常陽産研 NEWS, 東日本大震災と地域の産業と雇用の復興に向けて〜住民に寄り添った経 済活動が今後の地域を支える〜, 2012.3.1 発行, 常陽産業研究所

8)「住宅」(2012.3), 私が見続けた福島の一年, 2012.3.20 発行, 61 巻 3 号, 社団法人日本住宅協会 


\section{(4) 論文発表（国内誌 2 件、国際誌 0 件）}

丹波史紀 (2011)，東日本大震災による被災者の生活と貧困一主として福島県を例に一, 貧困研究,

(November. 2011) , Vol. 7

丹波史紀 (2012), 放射能污染からの避難と「災害弱者」福島に生まれ、住み、生きてよかったと 言える社会を, 『大震災と子どもの貧困白書』,かもがわ出版

\section{（5）WEB サイトによる情報公開}

http://fsl-fukushima-u. jimdo. com/

（6）口頭発表（国際学会発表及び主要な国内学会発表）

(1)招待講演国内会議_2 件、国際会議 0 件)

\begin{tabular}{|c|c|c|c|c|c|}
\hline $\begin{array}{c}\text { 2011年 } \\
\text { 10月8日, } \\
\text { 9日 }\end{array}$ & $\begin{array}{l}\text { 日本災害復興学会2011 } \\
\text { 年度学会大会「東日大 } \\
\text { 震災の復興を考える」 }\end{array}$ & 明治大学 & 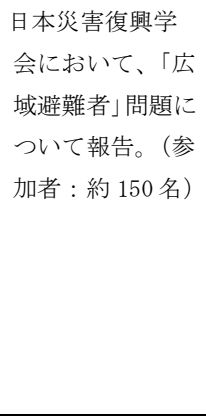 & $\begin{array}{l}\text { 日本災害復興 } \\
\text { 学会会員・東 } \\
\text { 北三県の被 } \\
\text { 災自治体 }\end{array}$ & $\begin{array}{l}\text { 日本災害復 } \\
\text { 興学会と } \\
\text { 連携し、今 } \\
\text { 後の被災 } \\
\text { 者援の } \\
\text { ネットワ } \\
\text { ークづく } \\
\text { りの議論 } \\
\text { につなが } \\
\text { った。 }\end{array}$ \\
\hline $\begin{array}{c}2011 \text { 年 } \\
11 \text { 月 } 19 \text { 日 }\end{array}$ & $\begin{array}{l}\text { 東北福祉大学 生活経済 } \\
\text { 学会 }\end{array}$ & $\begin{array}{l}\text { 東北福祉大学 } \\
\text { ステーションキ } \\
\text { ヤンパス館 }\end{array}$ & $\begin{array}{l}\text { 生活経济学会か } \\
\text { ら招聘され、福島 } \\
\text { の被災実態と実 } \\
\text { 装活動チームの } \\
\text { 取り粗みについ } \\
\text { て方向。(参加 } \\
\text { 者: 約 } 50 \text { 名) }\end{array}$ & $\begin{array}{l}\text { 郵便局等の生 } \\
\text { 活経済学会 } \\
\text { 加盟の会員 }\end{array}$ & $\begin{array}{l}\text { 福島の被災 } \\
\text { の実態を } \\
\text { 理解する } \\
\text { ことにつ } \\
\text { ながった。 }\end{array}$ \\
\hline
\end{tabular}

(2)口頭講演国内会議 0 件、国際会議 0 件)

(3)ポスター発表 （国内会議 0 件、国際会議 0 件）

\section{(7) 特許出願}

(1)国内出願（ 0 件）

1. “発明の名称、発明者、出願人、出願日、出願番号”

2 .

・.

(2)海外出願 ( 0 件)

1. “発明の名称、発明者、出願人、出願日、出願番号”

2 .

..

\section{（8）その他特記事項}




\section{VI 結び}

本実装活動は、避難生活を余儀なくされている被災者の仮設住宅における生活環境改善 のため実装活動である。それは、避難生活であっても「生活の質」を重視し、人々の生活 環境改善に努めることを狙いとしている。

実装活動は、主に仮設住宅およびサポート拠点のハード面と、被災者の支援や住環境の 整備などのソフト面を中心にしている。仮設住宅の建設においては、県内建設業者に一部 仮設住宅建設を発注するなど、地元の企業の仕事づくりや雇用創出などにも貢献する取り 組みにつながった。さらに、高齢者サポート拠点の設置を県内約20か所に展開することに もなった。こうした取り組みを経て、福島県と実装チームおよび関係する大学・研究機関 で、研究会を設置し、「福島型木造仮設住宅」の汎用化および仮設住宅の今後のあり方な どについて調査研究を重ねている。また実装支援プログラムの展開では、企業などの参画・ 連携も得ながら進めている。

またソフト面では、県大型仮設住宅団地に「高齢者サポート拠点」として、自治体とサ ポート拠点委託事業者、村の社会福祉協議会、実装活動チームの 4 者で定期的に会合を持 つなどし、サポート拠点の内容について意見調整をしながらすすめる取り組みにもつなが っている。また、県内のNP0団体のネットワーク組織である「ふくしま連携復興センター」 と連携し、仮設住宅団地における面的な環境アセスメントなどにも取り組んだ。

こうした取り組みは、2004年の新潟県中越地震さらに2007年の新潟県中越沖地震の被災 者支援の経験が生かされており、この取り組みについて「新潟日報」（2011.10.22）でも 大きく報道されたように、仮設住宅等の生活環境改善への取り組みへとつながっている。 また、実装支援プログラムの展開が新たな研究機関や企業との連携にも至っている。実装 支援プログラムの展開がきっかけとなり、さらに自治体・企業・NPOなど多様なステークホ ルダーの参画により被災地の復興に引き続き取り組む土壤ができあがった。今後継続的な 展開が期待されるところである。

ただし、今回の実装支援プログラムでは、当初予想していなかった事態も生まれ、課題 もあった。民間賃貸住宅を自治体が借り上げる、いわゆる「みなし仮設住宅」が急増し被 災者全体の支援のネットワーク化が今後の課題となっている。この点、被災自治体や県内N P0などと連携し、バラバラになった住民の絆を断ち切らず、コミュニティをどう維持して いくか、そのための枠組みをどう作り出すかは今後の課題である。

実装活動の展開をまとめると、災害時に起こる新たな事態に臨機応変に対応しなければ ならず、その点では過去の災害支援の経験だけでは対応できない面もあった。福島県のよ うに県内外に避難する住民がいる事態は、これまでの災害の想定を遙かに超える事態とも いえる。一方で、前述の福島県や関係研究機関との定期的な研究会を開催し、あらたな実 
装活動の展開にもつながった点は大いに評価できる。

一方、実装活動チームのメンバーの約半数が県外の者であるという点も地理的な条件によ って、実際の実装活動では苦労をした点でもある。今後はこうした実装活動の展開におけ る計画的な支援の実施にさらに心がけたいと思う。 